\title{
ADDITIONAL GROUND-WATER SUPPLIES FOR THE CITY OF ENID, OKLAHOMA.
}

\author{
By B. Coleman Renick.
}

\section{INTRODUCTION.}

In 1914 the United States Geological Survey published a brief report on ground water for irrigation in the vicinity of Enid, Okla., based on a rapid examination of the area by $\mathrm{A}$. T. Schwennesen. ${ }^{1}$ The present report is published in response to a request for a short ground-water survey for the city. The commissioner and the superintendent of the waterworks reported a shortage of water during the summer, especially in July and August. This survey was desired to furnish information bearing on a proposed increase in the city water supply. The writer was engaged from November 14 to 20, 1923, inclusive, in a field examination of the country about Enid and the region west of Ringwood. The manuscript report was transmitted to the mayor of Enid on December 8, 1923. In order to make close estimates of the quantity of water available it would, however, be necessary to study the region in detail for a period of at least several months. It is not within the scope of this investigation to make estimates of the costs of installation.

\section{ACKNOWLEDGMENTS.}

The writer wishes to express his appreciation of the hearty cooperation of the city commissioners; Mr. F. C. Magruder, city engineer; Mr. Cecil Harrison, superintendent of the city waterworks; and Mr. J. D. Bomford, consulting engineer. Mr. Harrison rendered valuable assistance by conducting the writer over the field, supplying information pertaining to the present waterworks, and furnishing data concerning test holes bored under his direction. Mr. Bomford supplied the base map from which the accompanying ground-water map (fig. 3) has been prepared. The hearty cooperation of the well drillers and other citizens greatly facilitated the work. An unpub-

\footnotetext{
${ }^{1}$ Schwennesen, A. T., Ground water for irrigation in the vicinity of Enid, Okla.: U. S. Geol. Survey Water-Supply Paper 345, pp. 11-23, 1914.
} 


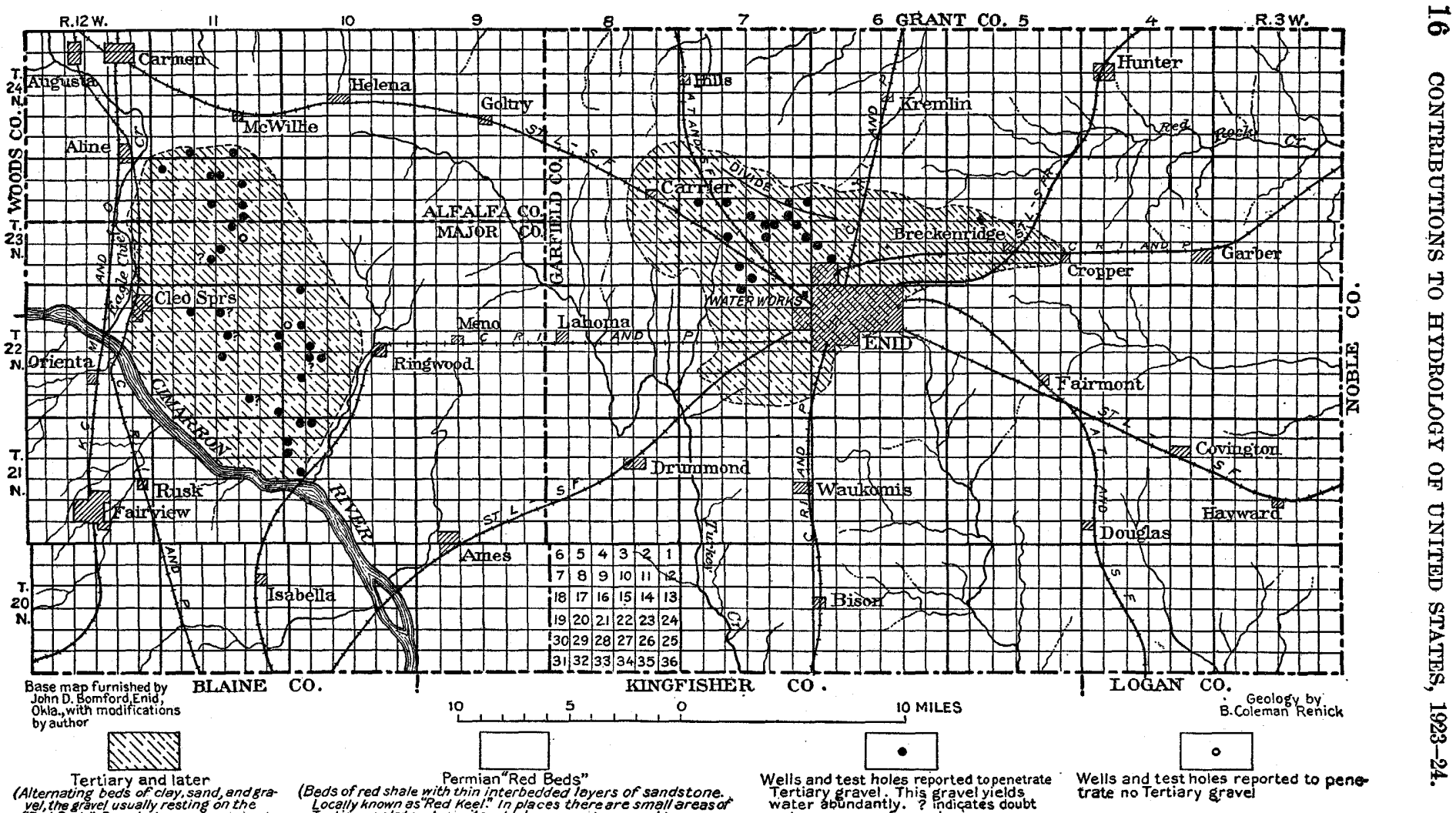

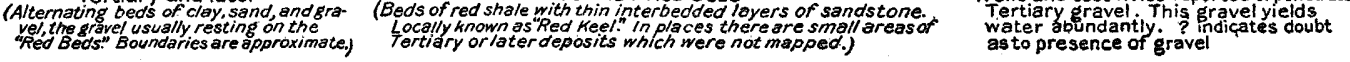

FrgURE 3.-Map of an area in the vicinity of Enid and Ringwood, Okla., showing distribution of water-bearing Tertiary and later deposits. 
lished report on the water supply of Enid, prepared by Messrs. Black \& Veatch, consulting engineers, and a short unpublished report prepared in October, 1923, by Messrs. Bomford and Magruder, were available for consultation.

The present report was carefully reviewed by O. E. Meinzer, geologist in charge of the division of ground water. The chemical analyses of five samples of water were made in the water-resources laboratory of the United States Geological Survey in Washington by C. S. Howard. The section of this report relating to the quality of water was prepared by W. D. Collins, chief of the division of quality of water. Several forms of showing diagrammatically the results of analyses of waters have been proposed. The form used in Figure 5, suggested by Collins, ${ }^{2}$ has here been adopted.

\section{GEOLOGY.}

Permian rocks.-The oldest rocks exposed in the region are of Permian age and consist of red shale and some thin lenticular beds of sandstone. The rocks are commonly referred to as the "Red Beds," and are locally known as "red keel."

Drilling operations have shown that the "Red Beds" (Permian and probably some underlying Pennsylvanian strata) are at least 3,300 feet thick. ${ }^{3}$ In many places it is difficult to determine the structure of these beds from their outcrops, and some oil companies have resorted to core drilling in order to work out the structural relations.

Tertiary and later deposits.-Resting uneonformably on the "Red Beds" are much younger deposits, the oldest presumably Tertiary. These younger deposits consist of gravel, sand, and clay. At most places the gravel rests on the "Red Beds." The pebbles of the gravel are almost entirely quartz and the matrix is quartz sand and clay. The larger particles of the gravel so far as observed, did not exceed three-eighths of an inch in diameter except, where they consist of fragments of "Red Beds." The gravel occurs in extremely lenticular beds and does not, as is commonly supposed, form a continuous sheet of uniform thickness. It has a maximum thickness of about 25 feet, but at many places in the areas of Tertiary deposits it is absent or is only a few inches thick. Sand of varying texture is encountered between the gravel and the surficial soil. Very commonly a layer of red or gray clay is interbedded in the sand that lies above the gravel. The maximum observed thickness of these deposits was 75 feet and the average thickness is 50 feet. (See fig. 4.) These beds are of terrestrial origin and are water-laid, with the

\footnotetext{
Collins, W. D., Graphic representation of water analyses : Ind. and Eng. Chemistry, vol. 15, No. 4, p. 394, April, 1923.

schwennesen, A. 'T., op. cit., pp. 11-23.
} 
exception of some of the surficial sand, which has been rehandled by the wind since its deposition and is therefore of eolian origin. There are two large areas of these Tertiary deposits, one in the vicinity of Enid, covering an area of about 110 square miles, and another west of Ringwood, covering an area of about 120 square miles. (See map, fig. 3.)

\section{WATER IN THE PERMIAN ROCKS.}

Although there are noteworthy exceptions, the "Red Beds" will at most places yield water in sufficient quantity for ordinary farm use, especially where the well encounters a lens of sandstone in the "Red Beds." The chemical character of the water in a well can not be predicted before drilling, as the water from wells on adjoining quarter sections may differ considerably in its content of dissolved salts. In general, however, the water from the "Red Beds" is more highly mineralized than that from the Tertiary deposits.

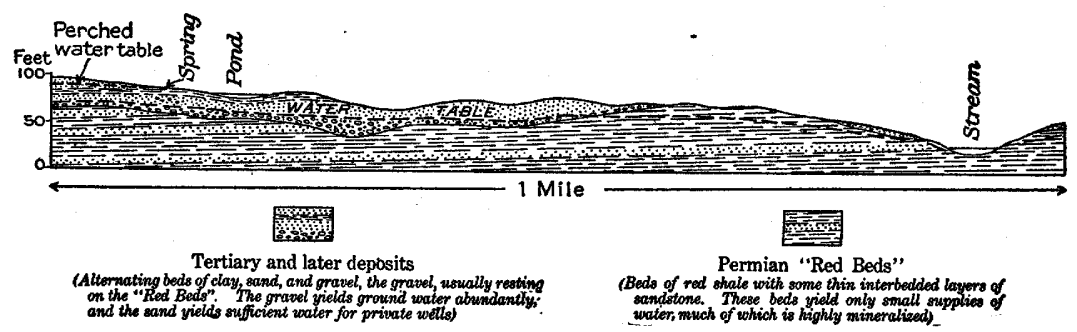

Figore 4.-Generalized diagrammatic section of rocks near Enid and west of Ringwood, Okla., showing ground-water conditions

\section{WATER IN THE TERTIARY AND LATER DEPOSITS.}

The largest supplies of ground water are obtained from the deposits of Tertiary and later age. The quantity of water yielded by any water-bearing bed depends to a great extent upon the texture of the material; the best water-bearers are the coarsest, cleanest, and least compacted gravels. The coarse sands yield enough water for small farm plants but are not sufficiently permeable to supply city wells. At some places the interbedded clay acts as an impervious layer separating two sandy water-bearing beds and produces a "perched water table." ${ }^{4}$ Such a table is common in the southern part of the Ringwood area, where one of these clay beds is especially persistent. (See fig. 4.)

\section{SOURCE OF GROUND WATER.}

The water found in wells in the "Red Beds" is derived in part from water that slowly migrates underground from more or less

4 Meinzer, O. E., Outline of ground-water hydrology : U. S. Geol. Survey Water-Supply Paper 494, p. 41, 1923. 
remote areas and in part from the water that is precipitated as rain and snow in the immediate vicinity. The water in the Tertiary deposits is derived entirely from precipitation within a few miles of the wells from which it is pumped and not from a remote source, as some have supposed.

\section{RELATION OF GROUND WATER TO TOPOGRAPHY, SOIL, AND VEGETATION.}

In a country that is underlain by porous and permeable materials, that is relatively flat and has few drainage lines, and that contains some undrained depressions, a considerable part of the water precipitated as rain and snow sinks into the soil and percolates downward to the water table. A porous and permeable material, such as sand, permits rapid migration of water downward and thus is favorable to a minimum evaporation. By evaporation from their leaves plants dissipate water which otherwise would percolate down to the water table and become available fo pumping from wells. In the areas of Tertiary deposits west of 1 ingwood and northwest of Enid the conditions are favorable for replenishing the groundwater supply because the country is relatively flat and contains undrained depressions, the soil is very permeable, and the vegetation is scanty.

The Ringwood area of Tertiary deposits is not dissected by streams and therefore has less loss of ground water from seepage than the Enid area, where in places the Tertiary beds are dissected and the "Red Beds" are exposed.

\section{PRESENT WATERWORKS OF ENID.}

Main plant.-The plant of the city pumping waterworks, which is in the SE. $\frac{1}{4}$ sec. 1, T. 22 N., R. 7 W., was installed in 1911. It originally consisted of a central pump pit about 30 feet deep and two tunnels, one of which extends toward the northwest and the other toward the east. Each tunnel contained 16 wells drilled about 27 feet apart. These wells are 6 inches in diameter and are connected to a suction main. A valve at each well regulates the quantity of water pumped. In 1918 the tunnels were lengthened and 16 wells of similar type and spacing were drilled in each tunnel. The average depth of all these wells is about 50 feet. Since this last extension was made three wells of larger diameter have been dug. These wells extend in a general northerly and northwesterly direction from 600 to 1,800 feet from the present plant. Two of them have pits 6 feet in diameter that extend to the water level, and below that galvanized casings, 30 inches in diameter, extending 14 and 17 feet, respectively, into water-bearing gravel. The third well, 20 feet in diameter, has a brick curbing and is 47 feet deep. 
Mr. Harrison, the superintendent of the waterworks, who kindly furnished the history of the plant, reported that this system will now yield an average of 900,000 gallons in 24 hours of pumping.

Wells on the King tract.-In 1919 the city of Enid extended its water system by installing 10 wells on the so-called King tract, in the SW. $\frac{1}{4}$ sec. 11, T. $22 \mathrm{~N}$., R. $7 \mathrm{~W}$. In each well a pit 6 feet in diameter extends to the water-bearing gravel and below this a 26 -inch perforated casing penetrates the gravel and rests on the "Red Beds." At each well a layer of coarse gravel has been placed around the perforated casing. The average depth of these wells is about 45 feet. An electric motor furnishes power for an individual pump at each well.

\section{CONSUMPTION OF WATER BY CITY OF ENID.}

Mr. Harrison reported that the average daily capacity of the main pumping plant is 900,000 gallons, and he estimated that the wells on the King tract also con ribute about 900,000 gallons, or that the total capacity of the wells at supply the city waterworks is about $1,800,000$ gallons daily, and that during a considerable portion of the year the city consumes the entire $1,800,000$ gallons each day.

\section{QUANTITY OF GROUND WATER.}

The average annual precipitation in the vicinity of Enid has been about 30.5 inches during the period of 25 years for which records have been obtained by the United States Weather Bureau. If the average annual precipitation is 30 inches, about $520,600,000$ gallons of water will fall on each section of land. If in the area of gravel one-third becomes ground water (the other two-thirds either running off or evaporating or being consumed by plants), about $173,870,000$ gallons will be contributed annually to the ground water on each section of land, or a daily average of about 470,000 gallons. If one-half of this amount can be recovered by pumping from wells, about 235,000 gallons daily is available from 1 square mile.

If these estimates are approximately correct it will require somewhat less than four sections to supply the 900,000 gallons a day that is pumped by the main plant and a similar area to supply the 900,000 gallons a day supplied by the wells on the King tract. The water utilized by the city does not, however, all come from an area of 8 square miles adjacent to the two pumping plants, for undoubtedly some of it finds its way to the pumps by slow underground flow from sections several miles away from the plants.

\section{QUALTTY OF WATER.}

The analyses of samples of water from the Tertiary areas of Enid and Ringwood (see p. 22) may be divided into two groups. The 
two samples from Enid are similar in composition. The samples from Ringwood are like one another but differ noticeably from those from Enid. (See fig. 5.)

The water at Enid is slightly hard and contains little dissolved mineral matter. It is not very different in composition from that of the public supply of Chicago. It can be used for most domestic purposes without great trouble from hardness. For use in large boiler plants or in commercial laundries, it should be softened. It

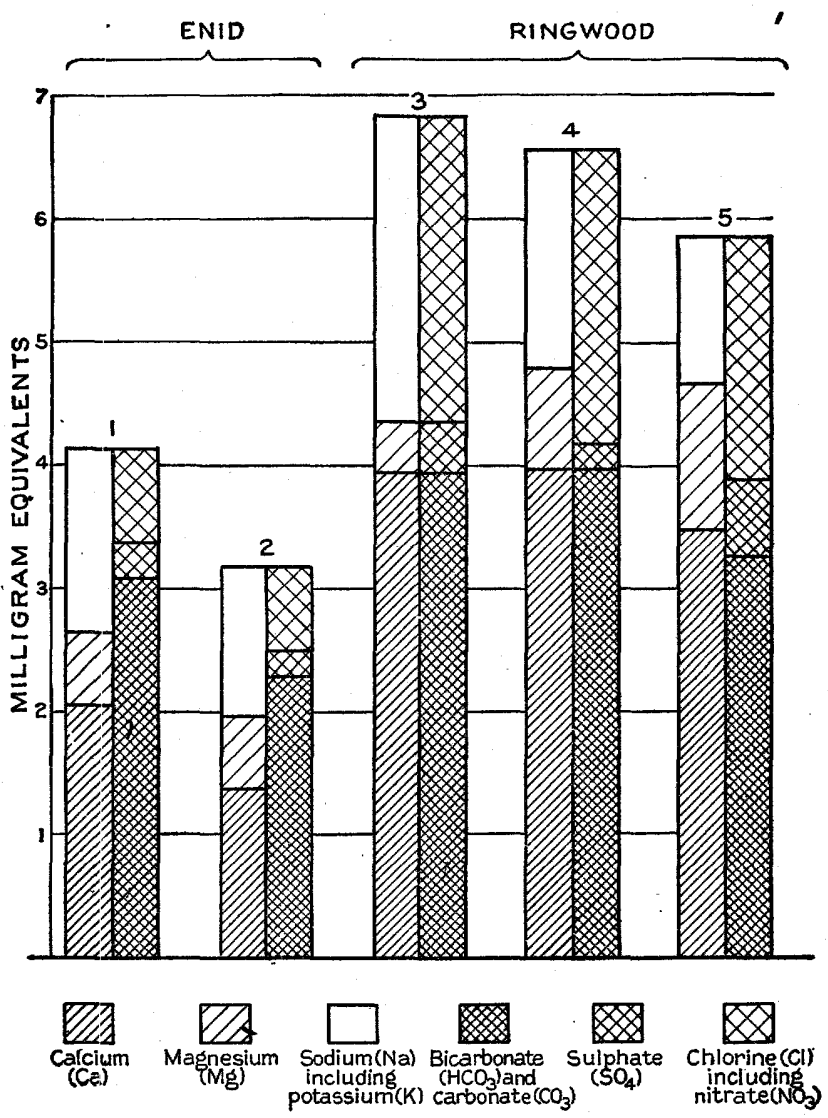

Figure 5.-Graphic representation of analyses of waters from Tertiary deposits near Enid and Ringwood, Okla. (See table, p. 22.)

should be satisfactory for use in boilers except that it may form a slight amount of soft scale.

The water from Ringwood is decidedly hard. Such water could profitably be softened for domestic use and for any industrial use in which hardness is detrimental. These waters may prove corrosive in steam boilers. In general the water at Ringwood has about the same composition as that at Enid but contains nearly twice the quantity of dissolved mineral matter. 
Analyses of water from Tertiary deposits at Enid and near Ringwood, Okla.

[Analyst, C. S. Howard. Parts per million.]

\begin{tabular}{|c|c|c|c|c|c|}
\hline & 1 & 2 & 3 & 4 & 5 \\
\hline 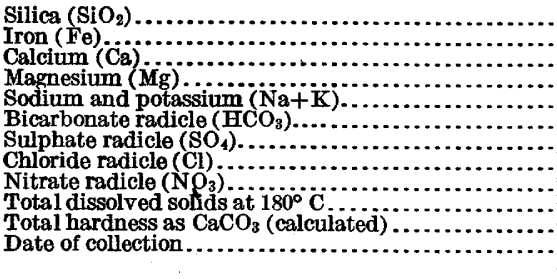 & $\begin{array}{c}\text { Trace. } \\
42 \\
7.8 \\
39 \\
182 \\
15 \\
26 \\
6.2 \\
137^{-2} \\
\text { Nov.20, } \\
1923 .\end{array}$ & $\begin{array}{c}26 \\
.12 \\
29 \\
7.5 \\
30 \\
145 \\
9.1 \\
21 \\
1.0 \\
199 \\
103 \\
\text { Nov.19, } \\
1923 .\end{array}$ & $\begin{array}{c}1.6 \\
5.7 \\
59 \\
238 \\
21 \\
84 \\
2.2 \\
221 \\
\text { Nov.15. } \\
1923 .\end{array}$ & $\begin{array}{c}26 \\
.12 \\
78 \\
9.6 \\
42 \\
244 \\
12 \\
91 \\
\text { Trace. } \\
425 \\
234 \\
\text { Nov.16, } \\
1923 .\end{array}$ & $\begin{array}{l}70 \\
15 \\
27 \\
200 \\
30 \\
69 \\
2.4 \\
236 . \\
\text { Nov. } 15, \\
1923 .\end{array}$ \\
\hline
\end{tabular}

1. Drilled well 50+ feet deep: SE, 1 sec 1, T, 22 N. R. 7 W. Enid. Owned by city. 2. Bored well 47 feet deep; SW. $\frac{1}{4}$ NE. 1 sec. 24, T. 23 N., R. 7 W., Enid. Owned by P. W. Dickman.

3. Drilled weil 57.5 feet deep; NE. sec. 20, T. 22 N., R. 10 E., Ringwood. Owned by A. K. Manning.

4. Drilled well 82 feet deep; SE. 1 sec. 12, T. 22 N., R. 12 W., Ringwood. Owned by Arnold Spenner.

5. Spring, SW. + SW. 1 sec. 22, T. 22 N., R. 10 E., Ringwood.

\section{PROSPECTING FOR WATER-BEARING GRAVEL.}

Some cities set about to develop a ground-water supply before testing the proposed well site thoroughly by drilling. At Enid there is a direct relation between the quantity of water that can be obtained and the thickness of the gravel that yields the water. The thickness of the gravel should therefore be determined before wells are drilled and a pumping system is installed. In areas where the gravel is thin or absent only small supplies can be expected.

In drilling test holes it is necessary to keep an accurate log of the hole, to collect samples for mechanical analyses at each change in the beds, and to collect samples of water for chemical analyses from certain holes, the number of samples collected depending on the number of holes drilled. Certain of the holes drilled should be tested by pumping and the drawdown measured. It should be remembered, too, that a well will yield water at a more rapid rate if it is pumped alone than if it is pumped simultaneously with other wells nearby. Moreover, a well will-yield at a more rapid rate in a pumping test of only a few hours or a few days than during a longer period, and estimates of yield based on pumping for a short period should therefore be reduced accordingly.

The total available supply of ground water and the extent of its depletion by pumping may be determined at relatively small cost by carefully observing the water level in a number of properly distributed wells sunk for this purpose into the saturated gravels. At Enid a few such observation wells should be maintained near the pumping plants; a few should be maintained in the area 3 miles north of Enid that is recommended for new development; and a few should be maintained at intermediate points and at places still farther from Enid. The elevations of definite reference points in 
these wells should be established by instrumental leveling. The depth to the water level from the reference point in each well should be measured from time to time, preferably about once a month. The measurements on all the wells should, if possible, be made on the same day. The data obtained by these observations will show the shape and the fluctuations of the water table in relation to rainfall and pumpage and will soon give a reliable means of estimating the supplies available and of determining future developments.

Obviously any new pumping system that might be installed should be located at a place where the gravel is reasonably thick over a considerable area, and where pumping will not withdraw any great quantity of ground water that would otherwise be recovered at one of the present plants.

It would be inadvisable to expand either the main plant or the plant on the King tract by drilling new wells, because the new wells would merely withdraw water that would otherwise be available to the present wells.

Fortunately there is at least one and possibly more than one locality near Enid and the large area west of Ringwood at which additional supplies may be obtained for the city. Each of these areas is discussed below.

\section{ENID AREA.}

Conditions are favorable to the accumulation of ground water in secs. $15,22,23,24$, the southern part of secs. 13 and 14, the northern part of secs. 25 , 26 , and 27, T. 23 N., R. 7 W., and in secs. 19 and 30 , T. 23 N., R. 6 W. (See fig. 3.) The area included in these sections is undissected by drainage lines and has many undrained depressions and a sandy, porous soil that is favorable to the seepage of water into the ground, and, according to well drillers and farmers, much of it is underlain by water-bearing gravel. Mr. P. W. Dickman, a well driller, gave from memory the following instructive information relating to the gravel, though the thicknesses given are only approximate:

Water-bearing materials reported in wells in an area north of Enid.

[All thicknesses are approximate.]

\begin{tabular}{|c|c|c|c|l|}
\hline T. N. & R. W. & Section. & Quarter. & \multicolumn{1}{|c|}{ Water-bearing material. } \\
\hline 23 & 7 & 13 & NE. & 7 feet gravel and sand. \\
23 & 7 & 13 & SE. & 15 feet gravel. \\
23 & 7 & 14 & NE. & 3 feet gravel. \\
23 & 7 & 14 & SE. & 1.5 feet gravel. \\
23 & 7 & 15 & SW. & $20 \pm$ feet gravel. \\
23 & 7 & 21 & SW. & $22 \pm$ feet sand and gravel. \\
23 & 7 & 22 & SE. & 30 feet sand and gravel, lower part coarse. \\
23 & 7 & 22 & NE. & 4 feet sand, fine. \\
23 & .7 & 22 & SW. & About same as SE. 1 sec. 22. \\
23 & 7 & 23 & NW. & 12 feet sand and gravel. \\
23 & 7 & 23 & NE. & 4 feet sand. \\
23 & 7 & 24 & NW. & 8 feet gravel. \\
23 & 7 & 25 & NE. & 20 feet gravel. \\
23 & 6 & 18 & NW. & 17 feet gravel and sand. \\
23 & 6 & 30 & SE. & 11 feet gravel and sand. \\
23 & 6 & 30 & NW. & 20 feet gravel and sand. \\
\hline
\end{tabular}


Secs. 23 and 24, T. 23 N., R. 7 W., should be carefully prospected to determine the thickness and depth of the gravel and adequate pumping tests should be made. Observations and calculations indicate that wells drilled in secs. 22,23 , and 24, T. 23 N., R. 7 W. would add considerably to the total water supply, though they would doubtless eventually cause some decrease of the supply at the main plant.

A well system installed about 3 miles northwest of the city of Enid will probably not greatly affect the water supply at the city plants, for wells in that area have suffered no appreciable drawdown since the main plant was installed at Enid, and the relative thinness of the saturated belt in the lower part of the Tertiary deposits precludes the possibility that the hydraulic gradient between the proposed area and the existing city plant will be much increased through the lowering of the water table by pumping at Enid. Hence, the movement of ground water from the area northwest of the city toward the existing pumping plants must remain very slow, despite the depletion of the supply in the vicinity of these plants. Furthermore, the lack of continuity of the gravel between these two areas indicates that the ground-water reserves of these two areas may be somewhat isolated from each other.

The sample of water (No. 2 in table on p. 22 and in fig. 5) from Mr. Dickman's well in the NE. $\frac{1}{4}$ sec. 24, T. 23 N., R. 7 W., is better than that of the present supply of Enid (No. 1, p. 22 and fig. 5) and is much better than the three samples taken from wells in the Ringwood area (Nos. 3, 4, 5, p. 22 and fig. 5).

No large supply of ground water can be obtained north of the divide, which is about 5 miles north of the court house at Enid (see map, fig. 3), because little gravel is found north of this divide. No undissected gravel-bearing tract that is of sufficiently large size to warrant development lies southwest of the city. Secs. 17 and 20, T. 22 N., R. 7 W., and all gravel-bearing sections to the west are dissected by streams that expose the "Red Beds" and break the continuity of the water-bearing gravel beds. South of the east-west half-section line in secs. $21,22,23$, and 24, T. 22 N., R. 7 W., the country is dissected by streams and the "Red Beds" are exposed at many places. Therefore only secs. $9,10,11,12,13,14,15,16$, and the northern part of secs. 21,22 , and 23, T. 22 N., R. 7 W., are favorable, and the wells on the King tract, in the SW. $\frac{1}{4}$ sec. 11 , undoubtedly exert considerable influence on the water table in the northeastern part of this area.

Before it is assumed that the city is obtaining all the ground water that it can procure near by, several test holes should be drilled northeast of the city, near the center of the area embracing secs. 19 to 34, inclusive, T. 23 N., R. $6 \mathrm{~W}$. The opinion prevails that the gravel is thin or absent over much of this area, and a few test holes would either substantiate or disprove this opinion. 
The broad plain east of Carrier, embracing secs. 12 and 13, T. 23 N., R. 8 W., and secs. $7,8,18,19$, and the western parts of secs. 17 and 20, T. 23 N., R. 7 W., is not a favorable area for obtaining additional water on account of its remoteness from Enid and the scarcity of gravel.

\section{RINGWOOD AREA.}

West of Ringwood, extending from Indian Creek on the east at least to Eagle Creek on the west, and from Cimarron River and Indian Creek on the south approximately to the north line of T. 23 $\mathrm{N}$. on the north (see fig. 3), is an area which, considered as to its lack of drainage lines, its abundance of undrained depressions, its high soil porosity, and the presence of underlying gravel, is favorable to the accumulation of ground water. Springs having a considerable flow of water were observed where the gravel is exposed along Indian Creek southwest of Ringwood and at Cleo along Eagle Creek. These gravel deposits, like those near Enid, are of Tertiary or later age. The eastern margin of this area is about 21 miles from the courthouse at Enid.

The Ringwood area is on the whole more favorable to the accumulation of ground water than the Enid area and is considerably larger. The water-bearing gravel overlies the "Red Beds" in most of this area but is not present everywhere, so that it will be necessary to prospect any proposed well field in order to determine the presence and the thickness of the gravel.

The surface of the Ringwood area slopes south-southeast, toward Cimarron River and Indian Creek, and undoubtedly the water-bearing gravel slopes in the same direction. Aneroid measurements, which were checked several times, show that the surface at Cimarron River stands less than 1,200 feet above sea level, and that the northern part of the gravel-covered area, about 15 miles away, at the northern border of T. $23 \mathrm{~N}$., stands more than 1,400 feet above sea level, giving a southward slope of about 15 feet to the mile.

When it is deemed necessary to utilize the Ringwood area, test holes should be drilled to test the thickness of the gravel in secs. 13 and 14, T. 22 N., R. 11 W., and sec. 18 and the W. $\frac{1}{2}$ sec. 17, T. 22 N., R. $10 \mathrm{~W}$., preferably in the southern parts of these sections. The altitude of the surface here is somewhat higher than at Enid and no static head would have to be overcome; but the friction head of the pipes for over 20 miles would prevent a sufficiently rapid gravity flow into Enid. The gravel probably rests on the "Red Beds" in the sections named. Wells drilled in these sections would intercept the southeastward-moving ground water. There is an adequate collecting area for ground water north of this prospective well field. The location of wells must depend upon the thickness of the gravel and the type of wells desired. Any well system developed in secs. 17 and 18, T. 22 N., R. 10 W., or in secs. 13 and 14, T. 22 N., 
R. 11 W., or both, might be extended toward the west into secs. 15,16 , and 17, T. 22 N., R. 11 W., and obtain additional supplies of water without interfering greatly with any existing system to the east, in secs. 13 and 14.

Until the maximum quantity of ground water available is obtained in the sections referred to above and to the north, developments should not be made southwest of Ringwood, near the junction of Indian Creek and Cimarron River, as has been suggested. Should the population of Enid become large enough to warrant the complete development of the Ringwood area test holes should be sunk in secs. 10,11 , and 12 , T. 21 N., R. 11 W., and sec. 7, T. 21 N., R. $10 \mathrm{~W}$. If these test holes penetrate gravel this locality would be favorable because wells at such a location would intercept the southeastward flowing ground water that would seep into the gravel south of the area recommended for first development, 5 or 6 miles to the north.

\section{PROPOSED EXTENSION.}

In order to increase the water supply at Enid the city must choose between two alternatives. Additional wells and a pumping system may be installed about 3 miles northwest of the main plant at relatively small cost or wells and a pumping system may be installed in the area west of Ringwood at much greater cost and the water piped to the city. With a proper installation at the locality about 3 miles north of Enid the city supply could probably be increased a net amount of $1,500,000$ gallons a day. By completely utilizing the Ringwood area the supply could be increased several million gallons a day.

In 1910 the population of Enid was 13,799, and in 1920 it was 16,576 -an increase of 2,777 in 10 years. Since 1920 the city has grown steadily. According to Mr. Harrison's estimate the present city water supply is about $1,800,000$ gallons a day. If by fully developing the locality north of Enid the supply can be increased $1,500,000$ gallons a day the aggregate supply would be $3,300,000$ gallons a day. A supply of 3,300,000 gallons a day would provide for a daily per capita consumption of 110 gallons to a population of 30,000 people, which should be adequate. If the present population of Enid is 18,000 and the water supply is $1,800,000$ gallons a day, the present average daily supply is 100 gallons per capita; if the present population is 23,000 the present supply is 78 gallons per capita.

If the city considers it desirable to develop the area west of Ringwood to the extent of $4,000,000$ gallons a day it will have a per capita supply of 172 gallons a day for 23,000 people, or 133 gallons for 30,000 people. 